\title{
PENGARUH PEMLASTIS NABATI TERHADAP SIFAT ELASTOMER TERMOPLASTIK BERBASIS CAMPURAN KARET ALAM/POLIPROPILENA
}

\section{THE EFFECT OF VEGETABLE PLASTICIZER ON THE PROPERTIES OF NATURAL RUBBER/POLYPROPYLENE BASED THERMOPLASTIC ELASTOMER}

\author{
Dwi Wahini Nurhajati*, Supraptiningsih, Nursamsi Sarengat \\ Balai Besar Kulit, Karet, dan Plastik, Jl. Sokonandi No. 9, Yogyakarta 55166, Indonesia \\ *Penulis korespondensi. Telp.: +62 274 512929, 563939; Fax.: +62 274563655 \\ E-mail: dwiwahini@yahoo.com
}

Diterima: 28 Agustus 2015 Direvisi: 13 Oktober 2015 Disetujui: 16 Oktober 2015

\begin{abstract}
Vegetable plasticizer is a plasticizer that is derived from renewable raw materials, used as an alternative to petroleum-based plasticizer. The purpose of this research was to compare the effect of the vegetable and petroleum plasticizers on the mechanical properties of thermoplastic elastomer (TPE). Vegetable plasticizer used in this study was a modified castor oil. Natural rubber/polypropylene (KA/PP) based TPE was made in an internal mixer at a temperature of $180^{\circ} \mathrm{C}$ with various $K A / P P$ ratio and type of plasticizer. In general, modified castor oil as a plasticizer has a more positive effect on the mechanical properties of TPE in various ratios of KA/PP, mainly related to improvement of properties of tensile strength, elongation at break and flexing resistance $100 \mathrm{kcs}$. The best formula of TPE is a TPE that is composed of KA/PP 60/40 using modified castor oil. XRD results showed that TPE is dominated by amorphous phase.
\end{abstract}

Keywords: castor oil, natural rubber, polypropylene, TPE.

\begin{abstract}
ABSTRAK
Pemlastis nabati merupakan pemlastis yang berasal dari bahan baku yang terbarukan yang digunakan sebagai alternatif untuk pemlastis berbasis minyak bumi. Tujuan penelitian ini untuk membandingkan pengaruh pemlastis nabati dengan pemlastis dari minyak bumi terhadap sifat mekanis elastomer termoplastik. Pemlastis nabati yang digunakan dalam penelitian ini adalah minyak jarak yang telah dimodifikasi. TPE berbasis campuran kompon karet alam (KA)/polipropilena (PP) dibuat di dalam internal mixer pada suhu $180^{\circ} \mathrm{C}$ dengan variasi perbandingan $\mathrm{KA} / \mathrm{PP}$ dan jenis pemlastis. Secara umum minyak jarak termodifikasi sebagai pemlastis mempunyai pengaruh yang lebih positif terhadap sifat fisis TPE pada berbagai rasio KA/PP terutama terkait perbaikan sifat kuat tarik, perpanjangan putus dan ketahanan retak lentur. Formula TPE terbaik adalah TPE yang dikomposisi dari KA/PP pada rasio KA/PP 60/40 menggunakan pemlastis minyak jarak. Hasil XRD memperlihatkan bahwa TPE hasil penelitian didominasi fasa amorf.
\end{abstract}

Kata kunci: karet alam, minyak jarak, polipropilena, TPE.

\section{PENDAHULUAN}

Elastomer termoplastik (thermoplastic elastomer $=$ TPE) merupakan suatu material yang mempunyai sifat termoplastis dan elastis, yaitu mirip dengan karet tervulkanisasi konvensional namun dapat dilelehkan seperti termoplastik pada suhu tinggi. Selain itu, TPE dapat diproses dan didaur ulang seperti bahan termoplastik. Karena pertimbangan lingkungan dan proses produksi yang menguntungkan, maka penggantian karet vulkanisat konvensional oleh TPE untuk pemakaian di industri terutama untuk industri otomotif tumbuh cepat. Produk TPE komersial tersebut umum-nya berbasis karet sintetik seperti ethylenepropylene-diene (EPDM), ethylene-propylene rubber (EPR) dan acrylonitrile butadiene rubber (NBR) atau modifikasinya sedangkan yang berbasis karet alam belum banyak dikembangkan. Hal ini disebabkan oleh spesifikasi teknis yang dihasilkannya relatif masih rendah dibandingkan 
dengan yang berbasis karet sintetik. Salah satu material yang dapat dikembangkan dari karet alam adalah kombinasi karet alam (KA) dengan polipropilena (PP) sebagai komponen termoplastik yang dikenal juga dengan thermoplastic vulcanizate (TPV). Beberapa peneliti sudah mengembangkan metode-metode untuk meningkatkan sifat dan morfologi TPE berbasis karet alam seperti Thitithammawong et al. (2012), meneliti pengaruh perbandingan belerang dan peroksida dalam sistem vulkanisasi campuran terhadap sifat vulkanisasi dinamik campuran KA dan PP. Passador et al. (2013) telah mempelajari pengaruh rasio pencampuran KA/PP dan vulkanisasi dinamik terhadap sifat-sifat reologi, termal, mekanikal, and morfologi yang menggunakan belerang (S)/ N-tert-butil-2-benzotiazol sulfenamida (TBBS) and tetrametil tiuram disulfida (TMTD) sebagai curative agent. Hasil penelitian menunjukkan TPE dari KA/PP dengan kandungan karet alam tinggi menunjukkan sifat mekanikal yang sangat baik dibandingkan campuran KA/PP yang tidak diikat silang terutama dari sifat tensile strength, Young's modulus dan kekerasan. Halimatuddahliana et al. (2008) telah memodifikasi vulkanisasi dinamik untuk menghasilkan produk termoplastik elastomer PP dan KA dengan perbandingan 70/30 (w/w) sulfur terakselerasi (1, 2, 3 bsk), dikumil peroksida (DCP) $(0,5 ; 1$; dan 1,5 bs PP) dan n,N -phenylenemaleimede (HVA-2) (2,3 dan 4 bsk) digunakan sebagai ikatan silang menghasilkan kekuatan tarik yang meningkat. Bahruddin et al. (2010) juga pernah melakukan penelitian pembuatan komposit KA/PP dengan bahan pengisi carbon black. Siregar et al. (2012) melakukan penelitian blend PP-SIR 10 dengan inisiator DCP dan crosslinker divinilbenzena. Pemlastis yang digunakan dalam penelitian tersebut umumnya adalah pemlastis yang berasal dari minyak bumi (petroleum oil) yaitu jenis minyak mineral seperti parafinik, naftenik dan aromatik.

Pemlastis yang berasal dari minyak bumi mempunyai kelemahan, antara lain tidak ramah lingkungan, menyebabkan iritasi, korosif dan bersifat karsinogenik. Oleh karena itu perlu adanya alternatif penggunaan pemlastis lain yang dapat diperbarui yaitu minyak yang berasal dari bahan nabati. Minyak nabati adalah salah satu senyawa organik yang menjanjikan yang dapat digunakan sebagai pemlastis karena murah, tidak beracun, dan ramah lingkungan. Flanigan et al. (2013) telah meneliti penggunaan bio-based plasticizers dari berbagai jenis palm oil, flaxseed oil, cashew nut shell liquid (CNSL) and low-saturated soybean oil (SBO) sebagai pengganti pemlastis berbasis petroleum untuk telapak ban dari karet. Menurut penelitian Nandanan (2000) minyak nabati dapat mengganti minyak aromatik maupun naftenik sebagai bahan pelunak kompon karet dengan bahan baku karet alam maupun karet sintetis. Cataldo et al. (2013) telah melakukan penelitian penggunaan biodiesel sebagai plasticizer pada formulasi telapak ban berbasis SBR. Pada penelitian ini akan digunakan minyak jarak sebagai pemlastis untuk mengganti pemlastis yang berasal dari minyak bumi.

Minyak jarak (castor oil) merupakan minyak kental berwarna kuning pucat, tidak mudah menguap dan tidak mengering. Minyak jarak umumnya adalah trigliserida dengan kandungan terbesar adalah asam lemak risinoleat yang mempunyai grup polar dalam asam lemak, terdiri dari tiga gugus hidroksil dan tiga gugus ikatan rangkap. Adanya asam lemak risinoleat pada minyak jarak membuat minyak jarak memiliki sifat yang khusus sehingga banyak digunakan sebagai bahan dasar industri, pelarut, pelumas, pewarna, resin, plasticizer, furnis, tinta, adesif, laminating dan pelapis. Asam risinoleat memiliki 18 atom karbon dengan 1 gugus hidroksi pada atom karbon ke-12 dan ikatan rangkap cis antara atom karbon 9 dan 10. Berat molekul asam risinoleat 298,46 . Penggunaan minyak jarak untuk pemlastis telah diteliti oleh Vibuthe et al. (2013) untuk pemlastis sabun cair, Nandanan (2000) untuk pemlastis karet alam maupun sintestis, Ghorui et al. (2011) untuk material komposit, Mazo et al. (2012) untuk cat, Phongtamrug et al. (2014) untuk sheet kompon PLA namun laporan hasil penelitian penggunaan minyak jarak untuk pada pembuatan TPE berbasis KA/PP belum ada. Sejumlah penelitian telah dilakukan untuk meningkatkan sifat-sifat minyak jarak sehingga dapat digunakan sebagai pemlastis. Salah satu metode tersebut adalah maleasi minyak jarak menggunakan maleat anhidrida dan minyak yang diperoleh dikenal sebagai maleated castor oil (MACO). Salah satu metode pembutan MACO seperti dijelaskan oleh Mazo et al. (2011), Ghorui et al. (2011), and Mistri et al. (2011). Reaksi maleasi yang dapat terjadi dapat digambarkan seperti Gambar 1.

Struktur kimia dari MACO terdiri dari rantai hidrokarbon yang panjang dan beberapa bagian yang dimodifikasi berasal dari anhidrida maleat. 


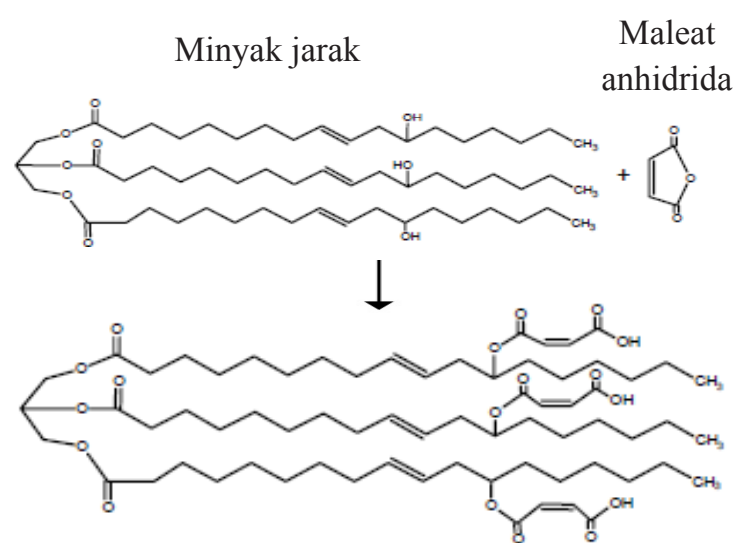

Gambar 1. Skema reaksi maleasi minyak jarak (Mazo et al., 2011).

Adanya bagian yang hidrofobik dan hidrofilik ini membuat MACO mungkin untuk bertindak sebagai pemlastis dalam matriks polimer seperti TPE. Selain itu, ester struktur kimia yang mengandung dan gugus asam karboksilat dapat berinteraksi dan membantu kompatibilitas dengan TPE menyebabkan perubahan sifat TPE.

Penelitian ini bertujuan untuk membandingkan pengaruh penggunaan pemlastis nabati yaitu minyak jarak dengan pemlastis yang berasal dari minyak bumi yaitu minyak parafinik terhadap sifat TPE berbasis campuran KA/PP.

\section{BAHAN DAN METODE Bahan Penelitian}

Bahan baku yang digunakan dalam penelitian ini adalah karet alam (SIR 10), resin polipropilena (PP) injection grade berbentuk butiran bening. Bahan aditif yang digunakan adalah aditif komersial yang banyak dijumpai di pasaran seperti $\mathrm{ZnO}$ sebagai aktivator, mercapto dibenzothiazole disulfide (MBTS) sebagai akselerator, $H A F$ black sebagai bahan pengisi, belerang sebagai $\mathrm{Cu}$ rative agent, dan minyak parafinik sebagai pemlastis diperoleh dari PT. Agronesia Divisi Barang Teknik Karet Bandung, minyak jarak (castor oil) sebagai pemlastis, asam stearat sebagai koaktivator, trimetilquinona (TMQ) sebagai antidegradan, polypropylene grafted maleic anhydride (PPg-MA) sebagai compatibilizer buatan Aldrich Chemical Co., antioksidan Irganox 1010 buatan Ciba-Geigy.

\section{Peralatan Penelitian}

Alat yang digunakan dalam penelitian ini meliputi peralatan untuk pembuatan kompon karet (berupa two-roll mill, dengan spesifikasi keliling lingkaran rol $51 \mathrm{~cm}$, diameter rol $16 \mathrm{~cm}$ dan panjang rol $33 \mathrm{~cm}$ ), peralatan untuk proses berupa internal mixer jenis Laboplastomill, peralatan untuk penyiapan spesimen pengujian mekanik berupa hydraulic hot press merek Gonno, peralatan uji meliputi: tensile strength tester merek Troning Albert tipe QC II-M-18, hardness tester merek Toyoseiki (Durometer D), densimeter elektron EW200SG merek Mirage, ross flexing machine untuk uji retak lentur, dan alat uji titik leleh menggunakan differential scanning calorimetry (DSC) merek Perkin Elmer, alat karakterisasi gugus fungsi FTIR merek Shimadzu- Prestige-21, karakterisasi kristalisasi $X$-ray diffraction merk Shimadzu, dan alat uji morfologi: scanning electron microscope (SEM) merek JEOL JSM-T330A.

\section{Metode Penelitian \\ Preparasi minyak jarak}

Minyak jarak (castor oil) yang memiliki tiga ikatan rangkap jika digunakan sebagai pemlastis akan berfungsi dengan lebih efektif bila dibuat dulu menjadi MACO. Pembuatan MACO menggunakan metode yang dikembangkan dari penelitian Mazo et al. (2011). Hasil karakterisasi dengan FTIR menunjukkan adanya reaksi antara minyak jarak dengan maleat anhidrida yang ditandai dengan peningkatan puncak $1644 \mathrm{~cm}^{-1}$ yang merupakan ikatan rangkap $\mathrm{C}=\mathrm{C}$ dan puncak $3450 \mathrm{~cm}^{-1}$ merupakan gugus- $\mathrm{OH}$ intensitasnya berkurang dibandingkan minyak jarak sebelum reaksi. Selain itu juga tidak adanya puncak anhidrida siklik pada 1779 dan $1849 \mathrm{~cm}^{-1}$ menunjukkan bahwa hampir semua maleat anhidrida telah dikonsumsi untuk bereaksi dengan minyak jarak. Minyak jarak termodifikasi yang dihasilkan berwarna kuning gelap, mempunyai angka asam 32,54 dan nilai ini lebih rendah dibanding angka asam hasil penelitian Vibuthe et al. (2013) yaitu sebesar 40,07 yang digunakan untuk pemlastis sabun cair.

\section{Pembuatan kompon karet}

Kompon karet merupakan campuran yang terdiri atas karet alam, asam stearat, $\mathrm{ZnO}$, MBTS, carbon black, plasticizer, dan sulfur yang dibuat dengan menggunakan two roll mixing mill. Formula kompon karet dikembangkan dari hasil penelitian Bahrudin et al. (2010). Namun pada penelitian ini jenis pemlastis yang digunakan adalah minyak parafinik dan minyak jarak termodifikasi yang masing-masing jumlahnya dibuat tetap $5 \mathrm{phr}$ (per hundred rubber). Proses pembuatan kompon 
dilakukan pada suhu kamar dengan urutan proses pencampuran sebagai berikut: pertama-tama karet dimastikasi, selanjutnya ditambahkan bahan aditif $\mathrm{ZnO}$ setelah homogen diikuti asam stearat. Selanjutnya ditambahkan bahan pengisi carbon black diselang-seling dengan pemlastis setelah homogen berturut-turut ditambahkan TMQ, MBTS dan terakhir belerang. Kompon yang diperoleh dimasukkan ke ruang kondisi selama minimal 24 jam.

\section{Pembuatan TPE}

Pembuatan TPE berbasis campuran kompon $\mathrm{KA} / \mathrm{PP}$ dilakukan dalam internal mixer Laboplastomill pada suhu $180^{\circ} \mathrm{C}$ dengan variasi perbandingan KA/PP: 40/60; 50/50; dan 60/40 seperti disajikan pada Tabel 1. Jumlah PP disini sudah termasuk compatibilizer PP-g-MA sebanyak 5 phr di setiap formula.

Plastik PP dilelehkan terlebih dahulu di Laboplastomill pada suhu $180^{\circ} \mathrm{C}$ selanjutnya dimasukkan compatibilizer PP-g-MA diikuti kompon karet dan dicampur hingga homogen, selanjutnya ditambahkan antioksidan. Waktu yang digunakan untuk proses 10 menit. TPE yang diperoleh kemudian dicetak menjadi bentuk lembaran (slab) untuk keperluan pengujian.

\section{Pengujian TPE}

Pengujian sifat mekanis TPE berbasis campuran KA/PP meliputi kuat tarik dan perpanjangan putus dengan metode ISO 37, densitas, kekerasan, dan ketahanan retak lentur dengan metode SNI 0778:2009. Uji titik leleh dilakukan menggunakan differential scanning calorimetry (DSC). Homogenitas pencampuran bahan TPE yang dicampur dalam internal mixer diamati melalui scanning electron microscope (SEM). Kristalinitas suatu bahan dapat diamati dengan melakukan pengujian struktur kristal dengan menggunakan alat X-ray diffraction (XRD).

\section{HASIL DAN PEMBAHASAN}

Sifat Mekanis TPE Berbasis KA/PP

Pada prinsipnya proses pemlastis adalah terjadinya dispersi molekul pemlastis ke dalam fase polimer. Sifat kuat tarik merupakan salah satu kriteria utama yang digunakan untuk mengetahui pengaruh pemlastis minyak jarak termodifikasi pada sifat mekanis TPE berbasis KA/PP. Pengaruh pemlastis terhadap sifat kekuatan tarik TPE disajikan pada Gambar 2.

Pada Gambar 2 terlihat bahwa secara umum pemlastis minyak jarak termodifikasi memberi sifat kuat tarik yang lebih tinggi dibandingkan dengan minyak parafinik pada berbagai rasio KA/PP. Hal ini menunjukkan bahwa efisiensi minyak jarak termodifikasi sebagai pemlastis dalam pengujian kuat tarik TPE lebih besar daripada minyak parafinik. Selain itu mungkin dikarenakan minyak parafinik yang sebagian besar tersusun atas hidrokarbon alkana mempunyai ukuran molekul lebih rendah dari minyak jarak termodifikasi sehingga lebih mudah untuk menempati ruang antar molekul dalam rantai

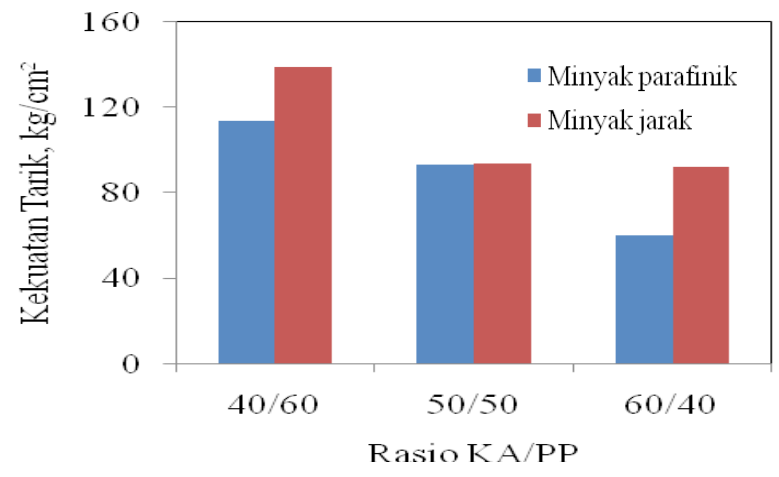

Gambar 2. Pengaruh jenis pemlastis terhadap sifat kekuatan tarik TPE pada berbagai rasio KA/ PP.

Tabel 1. Formula TPE

\begin{tabular}{|c|c|c|c|c|c|c|}
\hline \multirow{3}{*}{ Bahan, phr } & \multicolumn{6}{|c|}{ Formula TPE } \\
\hline & \multicolumn{3}{|c|}{$\begin{array}{c}\text { Pemlastis minyak parafinik } \\
\text { Rasio KA/PP }\end{array}$} & \multicolumn{3}{|c|}{$\begin{array}{c}\text { Pemlastis minyak jarak } \\
\text { Rasio KA/PP } \\
\end{array}$} \\
\hline & $40 / 60$ & $50 / 50$ & $60 / 40$ & $40 / 60$ & $50 / 50$ & $60 / 40$ \\
\hline Kompon Karet (KK) & 40 & 50 & 60 & 40 & 50 & 60 \\
\hline$P P+P p-g-M A$ & 60 & 50 & 40 & 60 & 50 & 40 \\
\hline Anti oksidan & 0,1 & 0,1 & 0,1 & 0,1 & 0,1 & 0,1 \\
\hline
\end{tabular}


polimer akibatnya mengurangi kekuatan sekunder diantara molekul polimer itu sendiri. Hal ini juga sependapat dengan yang ditulis oleh Vieira et al. (2011) yang menyatakan bahwa ukuran molekul rendah dari pemlastis yang memungkinkan untuk menempati ruang antar molekul antara rantai polimer, mengurangi kekuatan sekunder di antara mereka menyebabkan molekul polimer mudah bergerak sehingga bila ada ada tarikan tidak dapat menahannya dan menyebabkan putus. Selain itu juga mungkin minyak jarak termodifikasi dapat berinteraksi dengan TPE dan menginduksi kristalisasi dalam TPE.

Gambar 2 juga menunjukkan bahwa kuat tarik tertinggi $\left(139,157 \mathrm{~kg} / \mathrm{cm}^{2}\right)$ diperoleh untuk TPE dengan kandungan PP yang tinggi, ini berarti bahwa pemlastis lebih kompatibel terhadap plastik PP. Keadaan kompatibel bilamana pemlastis mempunyai gaya interaksi ke dalam fase polimer, proses dispersi akan berlangsung dalam skala molekul dan terbentuk larutan polimer pemlastis. Bila dilihat dari nilai parameter kelarutan (solubility parameter, $\delta$ ), maka parameter kelarutan karet alam adalah 16,6 $(\mathrm{MPa})^{1 / 2}$ (Robenson, 2007), $\mathrm{PP}=18,8 \quad(\mathrm{MPa})^{1 / 2}$, minyak parafinik= $14,2-15,3(\mathrm{MPa})^{1 / 2}$ dan castor oil $=18.3(\mathrm{MPa})^{1 / 2}$ (Cataldo, 2013). Parameter kelarutan $(\delta)$ sebanding dengan kekuatan interaksi antar molekul. Elastomer memiliki nilai $\delta$, pemlastis juga memiliki nilai $\delta$. Jika mereka mirip satu sama lain mereka cenderung lebih kompatibel. Kelarutan KA lebih rendah dari PP dan pemlastis minyak jarak termodifikasi namun lebih tinggi dari minyak parafinik, sedangkan kelarutan PP dan pemlastis minyak jarak termodifikasi hampir di kisaran yang sama. Hal ini menunjukkan bahwa PP dapat lebih berinteraksi dengan pemlastis minyak jarak termodifikasi dibanding dengan KA. Selain itu juga PP merupakan polimer yang mempunyai daerah kristalin sehingga rantai molekulnya lebih teratur dan rapat sehingga mempunyai kuat tarik yang lebih besar dibanding dengan KA yang mempunyai daerah amorf dengan susunan rantai molekul yang tidak teratur. Dari Gambar 2 juga terlihat semakin sedikit PP dalam TPE kuat tarik menurun, dimana untuk rasio KA/PP 60/40 mempunyai kuat tarik terendah yaitu $92,272 \mathrm{~kg} / \mathrm{cm}^{2}$. Namun nilai ini masih lebih tinggi dibanding TPE dengan rasio KA/PP 60/40 yang sama namun menggunakan minyak parafinik dimana memberikan nilai kuat tarik TPE lebih rendah yaitu $60,534 \mathrm{~kg} / \mathrm{cm}^{2}$. Hal ini juga menunjukkan bahwa minyak parafinik me- nempati ruang antar molekul antara rantai polimer sehingga mengurangi kekuatan sekunder di antara rantai polimer menyebakan molekul polimer mudah bergerak dan bila terkena tarikan menyebabkan mudah patah.

Pengaruh pemlastis terhadap sifat perpanjangan putus TPE pada berbagai rasio KA/PP disajikan pada Gambar 3. Perpanjangan putus (elongation at break) adalah persen pertambahan panjang yang terjadi untuk menarik benda uji sampai putus. Besarnya pertambahan panjang yang dialami oleh setiap benda ketika meregang adalah berbeda antara satu dengan yang lainnya, tergantung dari elastisitas bahannya.

Pada Gambar 3 terlihat bahwa secara umum pemlastis minyak jarak termodifikasi memberi sifat perpanjangan putus yang lebih tinggi dibandingkan dengan minyak parafinik pada berbagai rasio KA/PP. Hal ini menunjukkan bahwa PP dapat lebih berinteraksi dengan pemlastis minyak jarak termodifikasi dibanding dengan karet alam sehingga lebih elastis dibanding TPE yang berisi minyak parafinik. Perpanjangan putus tertinggi (140\%) diberikan oleh TPE yang berisi minyak jarak 5\% untuk rasio KA/PP 60/40. Perpanjangan putus terendah (35\%) dihasilkan oleh TPE dengan rasio KA/PP 60/40 yang berisi pemlastis minyak parafinik.

Pengaruh pemlastis terhadap densitas TPE disajikan pada Gambar 4. Gambar 4 memperlihatkan bahwa pemlastis minyak jarak termodifikasi hanya memberikan kenaikan densitas sekitar 1\% dari minyak parafinik untuk TPE dengan rasio KA/ PP 60/40 dan 60/40, sedangkan untuk TPE dengan rasio KA/PP 50/50 tidak berbeda. Hal ini mung-

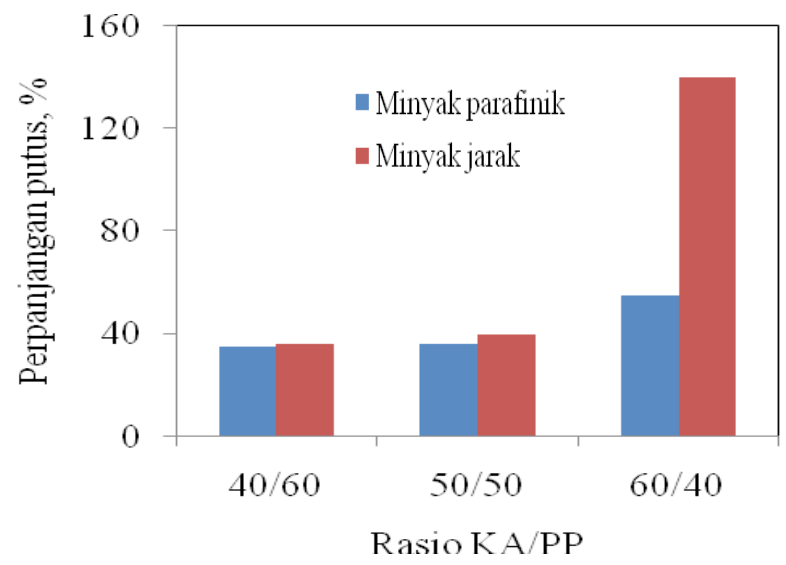

Gambar 3. Pengaruh jenis pemlastis terhadap perpanjangan putus TPE pada berbagai rasio KA/ PP. 


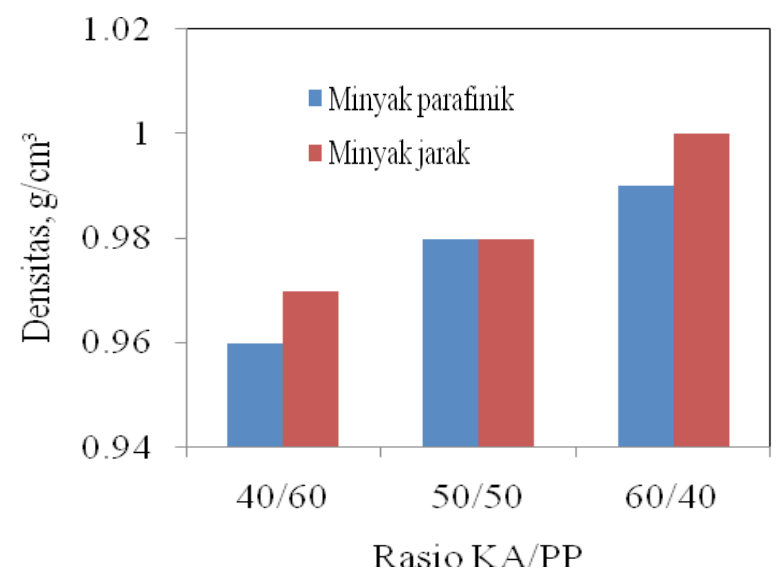

Gambar 4. Pengaruh jenis pemlastis terhadap densitas TPE pada berbagai rasio KA/PP.

kin dikarenakan secara umum densitas minyak jarak termodifikasi 0,985 (Vibuthe et al., 2013) sedikit lebih tinggi dari densitas minyak parafinik dari pertamina 0,8650-0,8735 (Pertamina, 2015), walaupun jika dilihat densitas kompon karet yang dibuat $\left(1,06 \mathrm{~g} / \mathrm{cm}^{3}\right)$ ini lebih tinggi dari densitas plastik PP, maka hal ini menunjukkan bahwa minyak parafinik yang mempunyai densitas lebih rendah dari minyak jarak termodifikasi tentunya lebih banyak mengisi volume kosong diantara rantai polimer karet dan PP.

Pengaruh pemlastis terhadap sifat kekerasan TPE disajikan pada Gambar 5. Kekerasan secara tidak langsung menunjukkan sifat kekakuan material. Plastikasi menurunkan kekerasan TPE karena viskositas turun. Pada Gambar 5 jelas terlihat bahwa kekerasan yang lebih rendah dari TPE berasal dengan penambahan pemlastis minyak jarak ke PP matriks. Ini berarti TPE dengan pemlastis minyak jarak lebih bersifat elastis karena PP dapat lebih berinteraksi dengan pemlastis minyak jarak termodifikasi dibanding dengan karet alam. TPE mengandung PP terbanyak (rasio KA/PP 40/60) menunjukkan kekerasan terendah yaitu 89 Shore A baik yang berisi minyak jarak termodifikasi maupun yang berisi minyak parafinik. Peningkat-

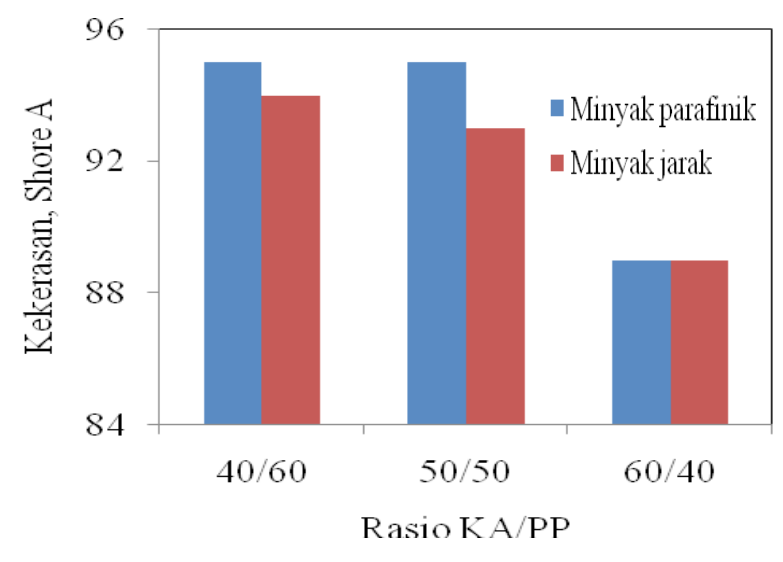

Gambar 5. Pengaruh jenis pemlastis terhadap kekerasan TPE pada berbagai rasio KA/PP.

an fleksibilitas plastik PP mungkin karena efek plastikasi itu dikaitkan dengan berkurangnya gaya antar molekul menyebabkan gerakan antar rantai lebih mudah bergerak, akibatnya bahan yang tadi keras dan kaku akan menjadi lembut pada suhu kamar.

Secara umum sifat kekerasan TPE hasil penelitian yang menggunakan pemlastis minyak jarak termodifikasi lebih rendah dibanding TPE yang menggunakan pemlastis minyak parafinik. Kekerasan tertinggi 95 Shore A ditunjukkan oleh TPE yang berisi minyak parafinik dengan rasio KA/PP 60/40 dan 50/50. Hal ini juga menunjukkan bahwa jumlah plastik PP tinggi akan memberikan kekerasan yang tinggi karena kekerasan vulkanisat kompon karet yang diteliti yang berisi minyak parafinik 43 Shore A dan yang berisi minyak jarak termodifikasi 40 Shore A lebih rendah dari pada kekerasan plastik PP.

Hasil uji ketahanan retak lentur TPE hasil penelitian dengan metode uji SNI 0778:2009 disajikan pada Tabel 2. Dari Tabel 2 terlihat bahwa semua TPE yang berisi minyak jarak termodifikasi pada berbagai rasio KA/PP: 40/60, 50/50, dan 60/40 tidak retak ketika diuji retak lentur 100.000 putaran, demikian juga untuk TPE dengan rasio

Tabel 2. Hasil uji ketahanan retak lentur TPE hasil penelitian.

\begin{tabular}{ccc}
\hline \multirow{2}{*}{ Rasio KA/PP } & \multicolumn{2}{c}{ Ketahanan retak lentur 100.000 putaran } \\
\cline { 2 - 3 } & Pemlastis minyak parafinik & Pemlastis minyak jarak termodifikasi \\
\hline $40 / 60$ & Tidak retak & Tidak retak \\
$50 / 50$ & Retak & Tidak retak \\
$60 / 40$ & Retak & Tidak retak \\
\hline
\end{tabular}


KA/PP 40/60 yang berisi minyak parafinik. Sedangkan TPE yang berisi minyak parafinik dengan rasio KA/PP 50,50 dan 60/40 retak ketika diuji pada 100.000 putaran. Hal ini juga terkait dengan fleksibilitas dari TPE tersebut karena PP dapat lebih berinteraksi dengan pemlastis minyak jarak termodifikasi dibanding dengan karet alam.

\section{Karakteristik TPE Berbasis KA/PP}

TPE berbasis KA/PP diharapkan bersifat seperti elastomer pada suhu kamar dan dapat meleleh seperti termoplastik. Oleh karena itu, TPE banyak digunakan dalam produk karet yang membutuhkan elastisitas dan dapat di daur ulang dengan panas atau diproses dengan peralatan termoplastik.

Sifat termal TPE yang berisi minyak jarak termodifikasi dalam hal ini titik lelehnya diuji menggunakan DSC dan hasilnya ditunjukkan
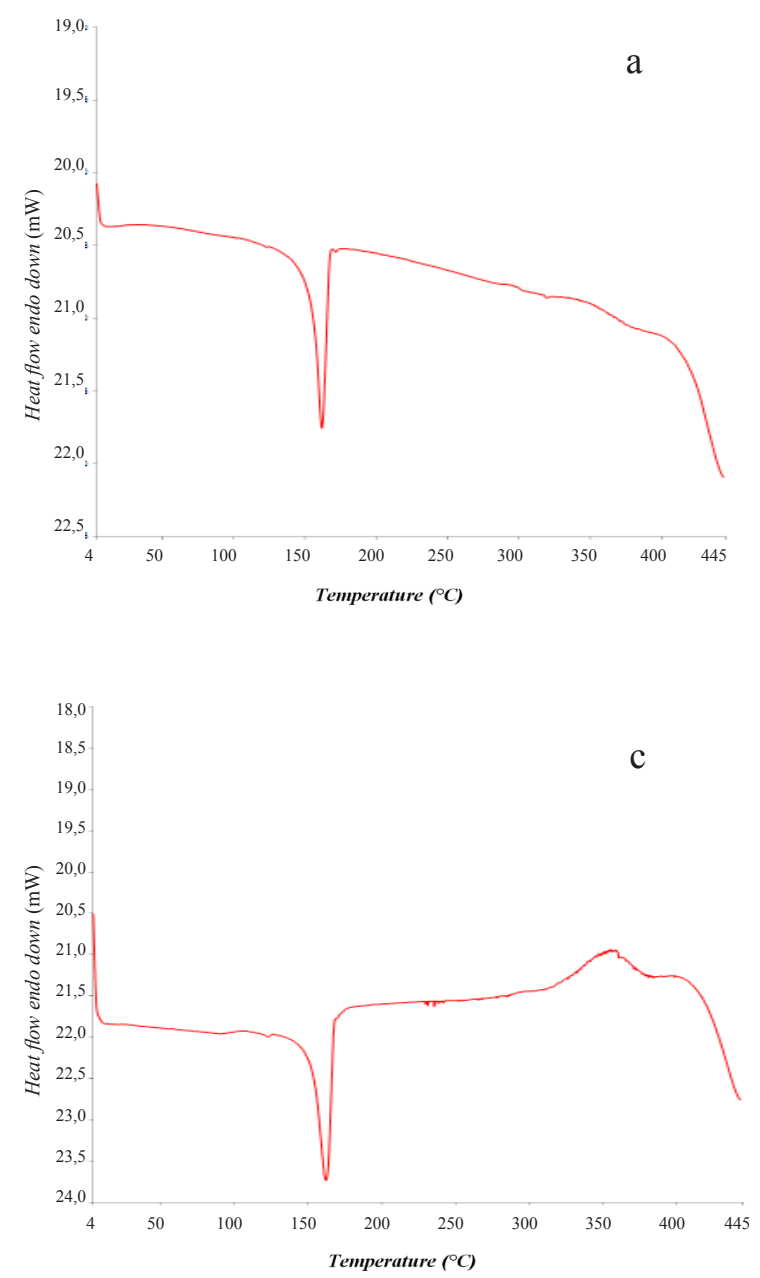

pada Gambar 6. Kurva TPE mempunyai model yang khas dengan dua puncak endotermis yang menunjukkan titik leleh dan suhu dekomposisi. Titik leleh menggambarkan perubahan fase dari padat menuju cair tanpa mengalami perubahan komposisi dan suhu leleh merupakan suhu kritis dimana polimer kehilangan kristalinitasnya secara keseluruhan. Suhu dekomposisi mempunyai pengertian suhu pada saat bahan mulai mengalami perubahan komposisi bahan-bahan penyusunnya.

Dari Gambar 6 terlihat bahwa TPE pada berbagai rasio KA/PP yang dihasilkan memiliki titik leleh, ini menunjukkan bahwa TPE tersebut adalah semi kristalin sehingga dapat diproses sebagaimana pemrosesan termoplastik. Terlihat juga bahwa komposisi kompon karet alam dalam campuran atau dalam TPE tidak mengubah suhu leleh yaitu relatif sama dengan suhu leleh PP $165^{\circ} \mathrm{C}$.
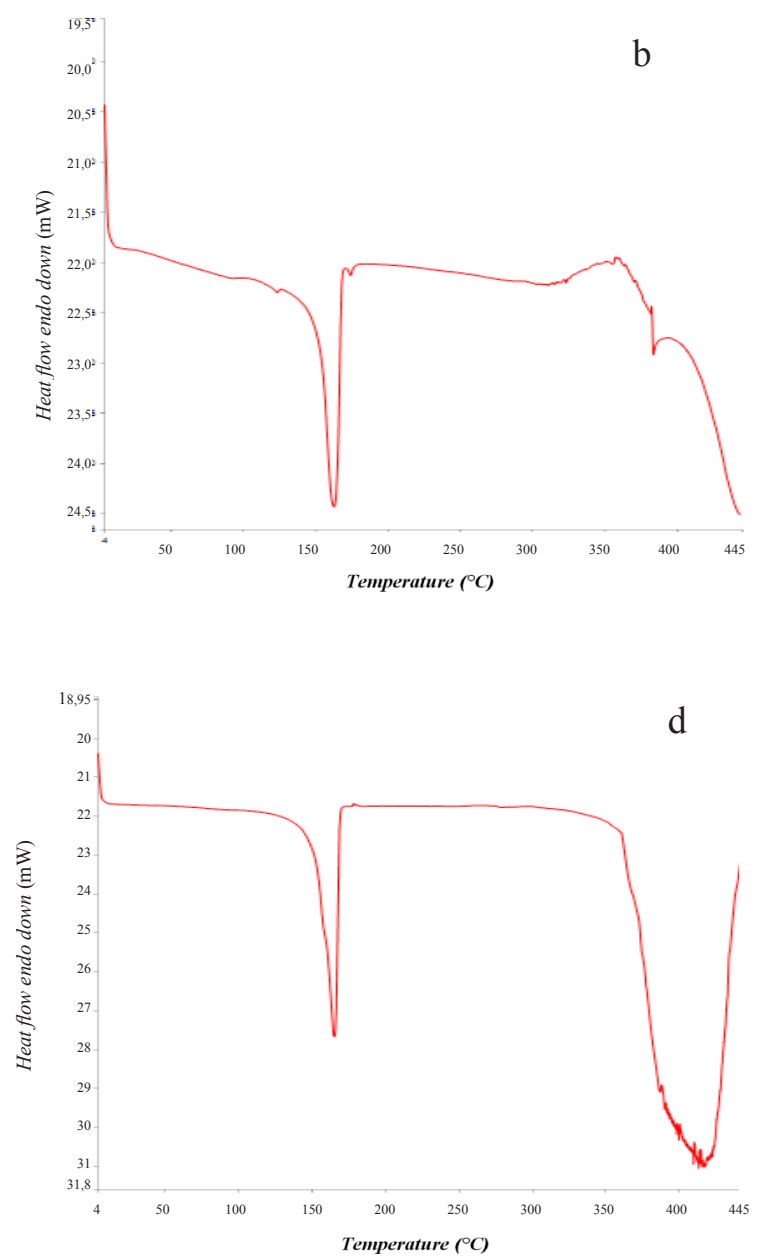

Gambar 6. Hasil uji titik leleh TPE yang berisi pemlastis minyak jarak pada berbagai rasio KA/PP menggunakan DSC: (a) TPE dengan rasio KA/PP 40/60, (b) rasio KA/PP 50/50, (c) rasio KA/PP 40/60, dan (d) plastik PP. 
Selain itu juga TPE pada rasio KA/PP 50/50 dan 60/40 memiliki suhu dekomposisi pada suhu seki$\operatorname{tar} 360^{\circ} \mathrm{C}$, namun untuk rasio KA/PP 40/60 tidak terlihat puncak tersebut demikian juga untuk PP.

Sifat polimer termoplastik umumnya mempunyai dua fase, yaitu fase amorf dan fase kristal. Daerah kristalin tersusun dari rantai molekul yang teratur dan rapat sehingga mempunyai kuat tarik lebih besar dibanding daerah amorf karena daerah amorf mempunyai susunan rantai molekul yang tidak teratur. Perbandingan antara fase kristal dan fase amorf disebut derajat kristalinitas. Penentuan derajat kristalinitas dilakukan dengan menggunakan metode sinar-X (XRD), hasilnya disajikan pada Gambar 7 dan 8. Dari Gambar 7 dan 8 terlihat bahwa TPE berbasis KA/PP yang berisi pemlastik minyak parafinik maupun minyak jarak didominasi fase amorf yang ditandai dengan adanya puncak difraksi yang melebar dan landai

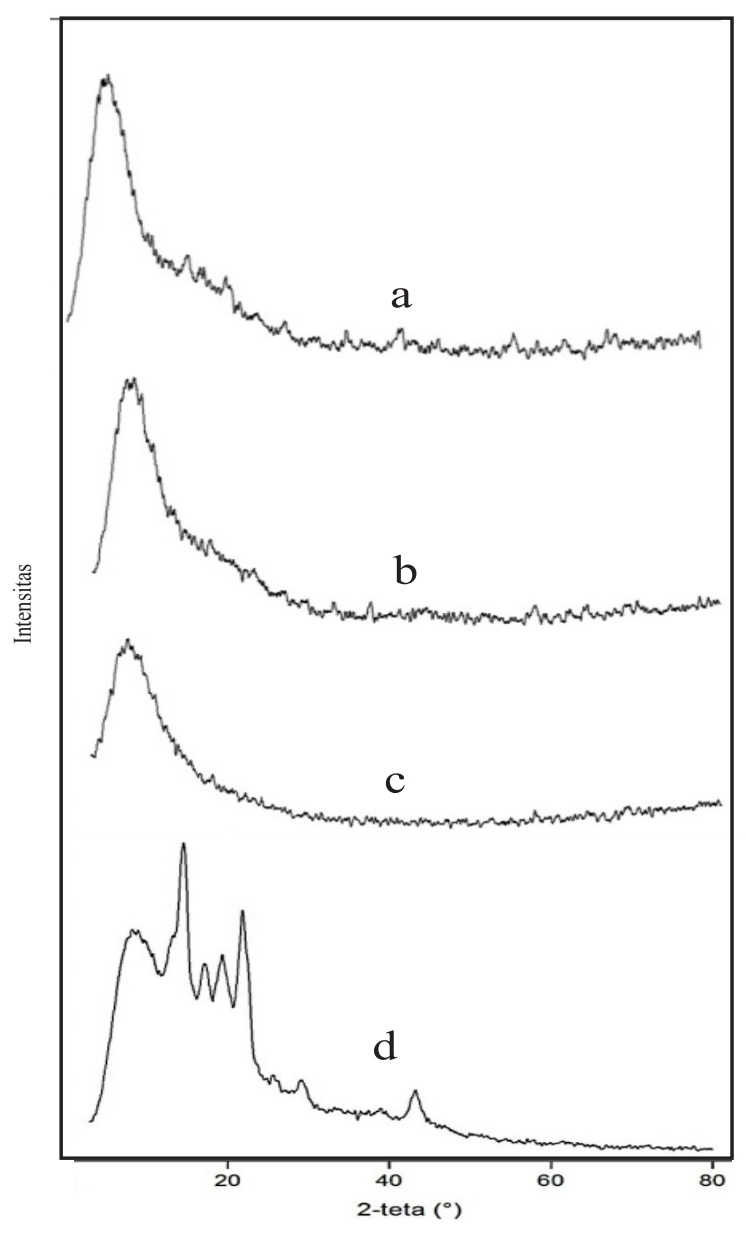

Gambar 7. XRD dari TPE dengan pemlastis minyak parafinik untuk berbagai formula: (a) KA/ PP 40/60, (b) KA/PP 50/50, (c) KA/PP 60/40, dan (d) XRD dari plastik PP. yaitu Gambar 7(a), 7(b), dan 7(c), serta Gambar $8(\mathrm{a}), 8(\mathrm{~b})$, dan 8(c), sedangkan plastik PP didominasi fase kristalin yang ditandai dengan pola difraksi yang menajam dan tinggi yaitu Gambar 7(d) dan 8(d). Fenomena ini terjadi disebabkan KA merupakan bahan yang mempunyai fase amorf.

Hasil analisa scanning electron microscope (SEM) TPE yang berisi pemlastik minyak jarak pada berbagai rasio KA/PP disajikan pada Gambar 9. Hasil analisa morfologi dengan SEM menunjukkan adanya pencampuran yang homogen antara kompon karet alam dengan plastik PP untuk formula TPE pada rasio KA/PP 40/60 (Gambar 9(a)), artinya KA terdispersi dengan baik ke dalam molekul PP. Dari Gambar 9 terlihat bahwa semakin banyak kompon karet yang ditambahkan maka distribusi plastik PP ke dalam kompon karet menjadi semakin sulit. Hal ini juga sejalan bahwa sifat kekuatan tarik dari TPE dengan rasio

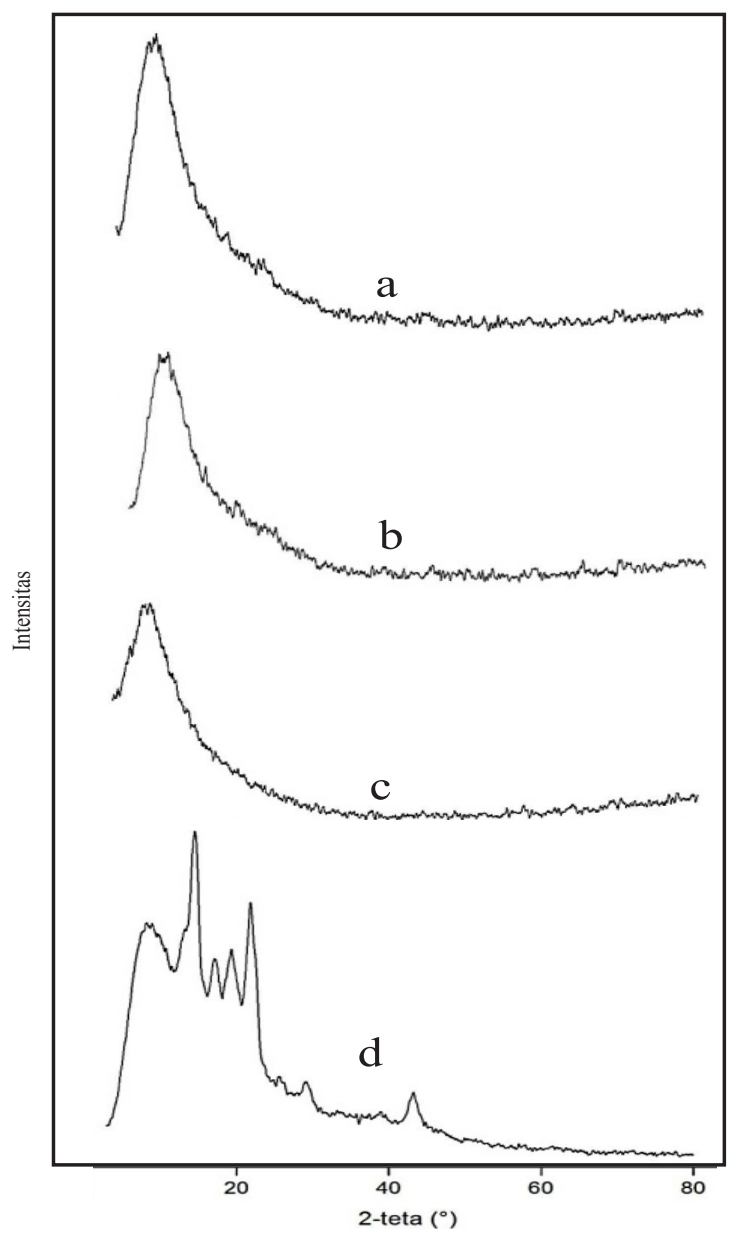

Gambar 8. XRD dari TPE dengan pemlastis minyak jarak untuk berbagai formula: (a) KA/ PP 40/60, (b) KA/PP 50/50, (c) KA/PP 60/40, (d) XRD dari plastik PP. 

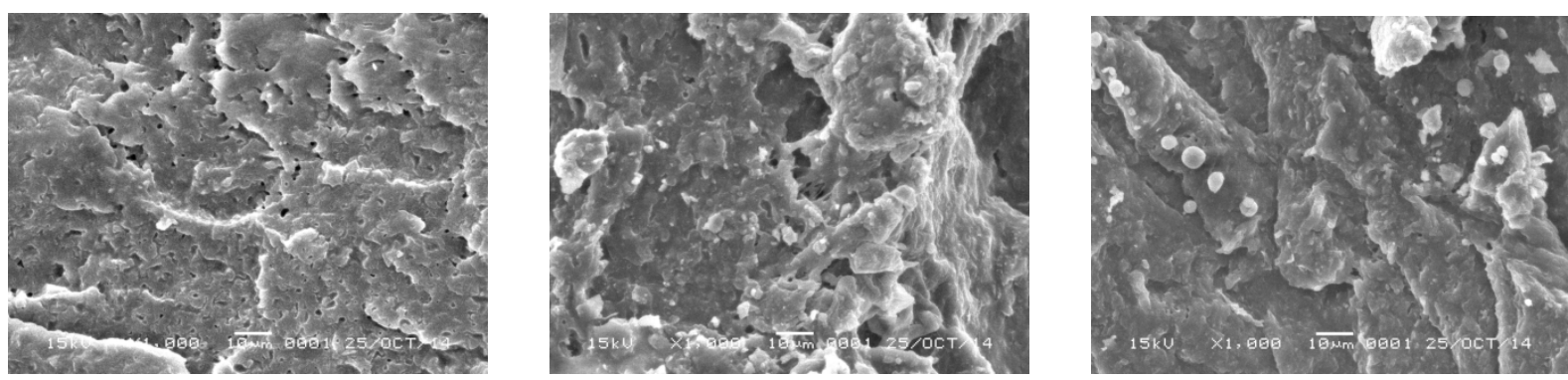

Gambar 9. Hasil analisa scanning electron microscope (SEM) TPE yang berisi pemlastis minyak jarak pada berbagai rasio KA/PP: (a) TPE dengan rasio KA/PP 40/60, (b) rasio KA/PP 50/50, dan (c) rasio KA/PP 60/40.

KA/PP 40/60 lebih baik dari TPE dengan rasio KA/PP 50/50 dan KA/PP 60/40.

\section{KESIMPULAN}

Secara umum penggunaan minyak jarak termodifikasi sebagai pemlastis nabati sebanyak 5 phr mempunyai pengaruh yang lebih positif terhadap sifat fisis TPE pada berbagai rasio KA/PP terutama terkait perbaikan sifat kuat tarik, perpanjangan putus dan ketahanan retak lentur.

TPE hasil penelitian dengan sifat fisis terbaik dikomposisi dari KA/PP 60/40. TPE terbaik dengan plasticizer minyak jarak tersebut mempunyai sifat fisis sebagai berikut: kuat tarik $=139,157 \mathrm{~kg}$ / $\mathrm{cm}^{2}$, perpanjangan putus $=33 \%$, densitas $=0,97 \mathrm{~g} /$ $\mathrm{cm}^{3}$, ketahanan retak lentur $100 \mathrm{kcs}$ adalah tidak retak, kekerasan 94 Shore A, dan titik leleh $165^{\circ} \mathrm{C}$. Hasil SEM memperlihatkan pencampuran homogen. Hasil XRD memperlihatkan bahwa TPE hasil penelian adalah amorf. TPE yang dihasilkan di sebut ramah lingkungan karena dapat di daur ulang dan menggunakan pemlastis nabati.

\section{UCAPAN TERIMA KASIH}

Penulis mengucapkan terima kasih kepada Kepala Balai Besar Kulit, Karet dan Plastik yang telah memberi kepercayaan untuk melakukan penelitian dan kepada Tim Kelompok Kerja 1866.001.001.017 tahun 2014 yang telah membantu penelitian ini sampai selesai.

\section{DAFTAR PUSTAKA}

Bahruddin, B., Zahrina, I., \& Amraini, S. Z. (2010). Pengaruh filler carbon black terhadap sifat dan morfologi komposit natural rubber/polypropylene. Jurnal Teknik Kimia Indonesia, 9(2), 62-68.

Cataldo, F., Ursini, O., \& Angelini, G. (2013). Biodiesel as a plasticizer of a SBR-based tire tread formulation. ISRN Polymer Science, 2013, 1-9.

Flanigan, C., Beyer, L., Klekamp, D., Rohweder, D.,
\& Haakenson, D. (2013). Using bio-based plasticizers, alternative rubber. Rubber \& Plastic News, 15-19.

Ghorui, S., Bandyopadhyay, N. R., Ray, D., Sengupta, S., \& Kar, T. (2011). Use of maleated castor oil as biomodifier in unsaturated polyester resin/fly ash composites. Industrial Crops and Products, 34(1), 893-899.

Halimatuddahliana, H., Surya, I., \& Maulida, M. (2008). Modifikasi bahan elastomer termoplastik polipropilena/karet alam (PP/KA) dengan proses pemvulkanisasian dinamik. Jurnal Penelitian Rekayasa, 1(2), 37-42.

Mazo, P. C., Estenoz, D., \& Ríos, L. A. (2011). Kinetics of the esterification of maleic anhydride with castor oil. Latin American Applied Research, 41(1), 11-15.

Mazo, P. C., Rios, L., Estenoz, D., \& Sponton, M. (2012) Self-esterification of partially maleated castor oil using conventional and microwave heating. Chemical Engineering Journal, 185, 347-351.

Mistri, E., Routh, S., Ray, D., Sahoo, S., \& Misra, M. (2011). Green composites from maleated castor oil and jute fibres. Industrial Crops and Products, 34(1), 900-906.

Nandanan, V. (2000). Studies on the use of drying oils as ingredients in the vulcanization of elastomers (Thesis). Cochin University of Science and Technology, India.

Passador, F. R, Rojas, G. J. A., \& Pessan, L. A. (2013) Thermoplastic elastomers based on natural rubber/polypropylene blends: Effect of blend ratios and dynamic vulcanization on rheological, thermal, mechanical, and morphological properties. Journal of Macromolecular Science, Part B: Physics, 52(8), 1142-1157.

Pertamina (2015). Refinery unit IV. http://www.pertamina.com/en/our-business/downstream/refinery/ refinery-unit/refinery-unit-iv/content, diakses 2 April 2015.

Phongtamrug, S., Chaipanithan, C., \& Jiruttisakul, N. (2014). Effect of modified oil on thermal properties and mechanical properties of poly(lactic acid) 
compressed sheet. The Journal of Industrial Technology, 10(1), 29-37.

Robeson, L. M. (2007). Polymer blends: A comprehensive review. Munich, Germany: Hanser.

Siregar, A. H., Muis, Y., \& Daulay, D. S. (2012). Preparation of thermoplastic elastomer from polypropylene-SIR 10 rubber blends with addition of dicumil peroxide as initiator and divinylbenzene as a crosslinker. Journal of Chemistry and Chemical Engineering, 6(12), 1099-1105.

Thitithammawong, A., Uthaipan, N., \& Rungvichaniwat, A. (2012). The effect of the ratios of sulfur to peroxide in mixed vulcanization systems on the properties of dynamic vulcanized natural rubber and polypropylene blends. Songklanakarin Journal of Science and Technology, 34(6), 653-662.
Vibhute, B. P., Khotpal, R. R., Karadbhajane, V. Y., \& Kulkarni, A. S. (2013). Preparation of maleinized castor oil MCO by conventional method and it's application in the formulation of liquid detergent. International Journal of ChemTech Research, 5(4), 1886-1896.

Vieira, M. G. A., da Silva, M. A., dos Santos, L. O., \& Beppu, M. M. (2011). Natural-based plasticizers and biopolymer films: A review. European Polymer Journal, 47(3), 254-263. 